\title{
Inductive Learning Methods towards Learning Outcomes
}

\author{
Mustika Fitri*, Dian Budiana, Adang Suherman \\ Fakultas Pendidikan Olahraga dan Kesehatan \\ Universitas Pendidikan Indonesia \\ Bandung, Indonesia \\ *mustikafitri@upi.edu
}

\begin{abstract}
This study compares a class implementing a deductive learning method and a class implementing inductive learning method on Pedagogical Issues subject on Sport Education students at a postgraduate degree in Universitas Pendidikan Indonesia. The method is an experimental research method. It has been found that both them show no difference in terms of the quality of learning outcomes. Therefore, it can be inferred that there is no single method best applicable in every situation in education. When compared with the results of this study, this gives a new color where both deductive methods and inductive methods have the same effectiveness in one context. This can be a contribution to the scientific field of education where one method cannot be generalized to be effective in all fields.
\end{abstract}

Keywords-deductive; inductive; learning method; physical education; pedagogical issues

\section{INTRODUCTION}

In physical education and sports, pedagogical issues play an important role because they are related to teacher competence in implementing learning both in class and outside the classroom [1]. For post graduate students who are also prospective lecturers, understanding of pedagogical issues become more important. It because they may teach prospective physical education teachers. Then, the prospective physical education teachers will transform the knowledge and experience they have gained during college. Understanding of pedagogical content knowledge in sports and physical education are also important. It is closely related to the didactic abilities of prospective educators in the field of physical education and sport [2].

\section{A. Deductive Method is Better than Inductive One}

Another study argues that the adoption of formal deductive procedures can represent an important step for assuring conviction in qualitative research findings called "pattern matching" [3]. Other studies reveal the phenomenon that that students learn simple morphosyntactic rules better under conditions of explicit-deductive learning [4,5].

\section{B. Inductive Method is Better than Deductive One}

Learning by using deductive and inductive methods actually have been implemented in various disciplines. In
Linguistics, for example, two English grammar classes are compared one class is taught by deductive method and the other class by inductive one [6]. The research proves that in the context of grammar learning, inductive learning is more effective than deductive one. It is proven that students are better prepared to face challenges and problems in the classroom when taught by inductive methods.

Another finding from the study was that it turned out that students were more actively involved in the learning process than students. Other studies still in the field of linguistics are conducted Qi and Lai, where both of them examine 2 classes of CSL (Chinese as a Second Language) [7]. Again, those classes are taught by inductive and deductive methods. The result proves that inductive research is more effective in teaching the Speech Act for Chinese-speaking students as a second language. They further state that inductive methods are more effective. They provide more space for active participation and problem solving for students.

Inductive approaches involve construction theory where the students must generate relevant principles by finding a common relationship behind a set of variables that work. Moreover, training in inductive reasoning requires forming theories and conclusions based on features of a small sample or a case study in the specified context [8].

\section{Both Methods are Great}

Meanwhile, in the medical field, research was conducted Marei et al., where they study two classes [9]. Those cover medical students at the University of Zagazig, Egypt. They are studying the sequencing of VP (Virtual Patients) with deductive and inductive methods. In this study, there were no significant differences between classes using deductive methods and classes that used inductive methods. In the field of physical education and sports, a study Lahti, found that there are no significant differences between classes using deductive methods and classes using inductive methods [10]. The research Lathi, which is conducted at The University of Minnesota, United States divides 2 Sports Science student classes [10]. The effectiveness is analyzed. Then, it is proved that there are no significant differences between classes using deductive method and inductive one. 
Positive feedback demonstrates that the deductive process enhanced both learning and application of theory to practice. The inductive process forced students to think through observed relationships and phenomena to draw generalizations. The result affirms Lott's assertion of the effectiveness of both the inductive and deductive processes [11].

A number of studies have examined the efficacy of inductive and deductive approaches [12] with different designs or populations and the results are not consistent [13].

These facts show that there are different points of view related to deductive and inductive learning. In fact, as discussed earlier, understanding of pedagogical issues is an important component for postgraduate students in Physical Education, especially since most of them are projected as lecturers who will teach prospective sports teachers and physical education. Therefore, this study aims to compare learning outcomes between deductive methods classes and inductive ones in the subject of Pedagogic Issues. Furthermore, this study also investigates whether or not there are differences in active participation in gender based learning.

\section{RESEARCH METHOD}

\section{A. Research Site}

The study is conducted at the School of Postgraduate Studies, Universitas Pendidikan Indonesia. The research begins in March 2018 and ends in November 2018. Data collection starts from the pretest process to divide the inductive and deductive groups which each group of students has the criteria of high achievers, middle achievers, and low achievers. Then the treatment until post-test is carried out starting in July 2018.

\section{B. Research Method}

The method used in this study is the experimental method with the design of The Two Group Posttest Only, by giving treatment to both groups. The Inductive group is treated by providing learning of articles from the first to the last meeting. The deductive learning group is given pedagogical source book learning at the initial to midterm meeting and continued with the article until the end.

There are two variables in this study, namely the independent variable and the dependent variable. The independent variable is pedagogical issues subject learning while the dependent variable is the inductive and deductive method.

\section{Research Design}

\begin{tabular}{llll}
\hline Treatment group & $\mathrm{M}$ & $\mathrm{X}_{1}$ & $\mathrm{O}$ \\
\hline Control Group & $\mathrm{M}$ & $\mathrm{X}_{2}$ & $\mathrm{O}$
\end{tabular}

Fig. 1. The matching posttest only control group design.

In this study, two classes that both contracted Pedagogical Issues courses are compared to the learning outcome. The first class applies the deductive method and the other class uses the inductive method. Thus, the initial hypothesis is as follows:
Ho $=$ there is no significant difference between the class using the deductive method and the class using the inductive method seen from the learning outcome in the Pedagogic Issues course.

\section{Research Participants}

Participants in this study are consisted of 2 lecturers and 4 classes of the Post Graduate Studies of Sports Education Study Program in the Indonesia University of Education. These lecturers are experts in the fields of physical and sports education. Four students who take the credit of Pedagogical Issues courses are further divided into 2 groups selected by means of total sampling. They fulfil the criteria to be studied. The first class is taught using deductive. The second one uses inductive method. Each class consists of 51 students.

\section{E. Data Collection}

To collect the data, the researcher makes the instrument assessment, scale of active participation, and class observations for 16 sessions. The researcher conducts observation and fill the observation sheet for the track record of learning implementation. To obtain valid and reliable data, triangulation is carried out by following up on observations through interviews. Semi-structured interviews are conducted to two lecturers, three student representatives from each class, and 3 female student representatives from each class. The 3 students are selected based on the criteria of high achievers, middle achievers, and low achievers.

\section{F. Data Analysis}

The results of collecting quantitative data are analyzed statistically using SPSS for Windows. Meanwhile, the results of observations and interviews are analyzed by coding and categorizing based on the formulation of the problem and the purpose of the study.

\section{G. Teaching Procedure}

As discussed in the Introduction chapter, the output of the Pedagogical Issues course is in the form of a research proposal. The first class implements deductive method. The study begins with studying theoretical texts relating to pedagogical issues in physical education and sports. Meanwhile, the second class uses inductive methods, begins learning by dissecting articles, especially research articles. The research articles deal with pedagogical issues in physical education and sports. With these two different approaches, students from each class must find a research gap from the proposals they make from two perspectives. The class with deductive methods must be able to explore the novelty and originality of their research based on theoretical texts while classes with inductive methods must be sharply able to analyze research gaps from existing related researches. In connection with the teaching procedures in detail, basically the two classes followed what the lecturer had designed in the lesson plan of the course. 


\section{1) Lesson plan of deductive method}

TABLE I. LESSON Plan OF Deductive MethoD

\begin{tabular}{|c|c|}
\hline Meeting & Materials \\
\hline 1 & $\begin{array}{l}\text { Pengenalan Materi Isu Pedagogi dalam Olahraga selama } \\
\text { satu semester }\end{array}$ \\
\hline 2 & Merespon Bab 2 Pedagogi Olahraga \\
\hline 3 & Merespon Pidato Guru Besar Prof Adang \\
\hline 4 & Merespon buku Realitas Kurikulum \\
\hline 5 & Merespon buku Revitalisasi Pengajaran dalam Penjas \\
\hline 6 & $\begin{array}{l}\text { Bedah Artikel "Implementation of the Personal and Social } \\
\text { Responsibility Model to Improve Self Efficacy during } \\
\text { Physical Education Classes For Primary School Children" }\end{array}$ \\
\hline 7 & $\begin{array}{l}\text { Bedah Artikel } \\
\text { "The Influence of the Sport Education Model on amotivated } \\
\text { students' in-class physical activity" }\end{array}$ \\
\hline 8 & UJIAN TENGAH SEMESTER \\
\hline 9 & $\begin{array}{l}\text { Bedah Artikel } \\
\text { "Teaching Responsibility Through Sport Education: } \\
\text { Prospects of a Coalition" }\end{array}$ \\
\hline 10 & $\begin{array}{l}\text { Bedah Artikel } \\
\text { "Body Mass Index, Physical Activity, and the Risk of } \\
\text { Decline in Overall Health and Physical Functioning in Late } \\
\text { Middle Age" }\end{array}$ \\
\hline 11 & $\begin{array}{l}\text { Bedah Artikel } \\
\text { "The effects of a 2-Year Physical Education Program } \\
\text { (SPARK) on Physical Activity and Fitness in elementary } \\
\text { School Students" }\end{array}$ \\
\hline 12 & $\begin{array}{l}\text { Bedah Artikel } \\
\text { "Student Physical Activity Levels During a Season of Sport } \\
\text { Education" }\end{array}$ \\
\hline 13 & $\begin{array}{l}\text { Bedah Artikel } \\
\text { "Effects of Adventure-Physical Education on High School } \\
\text { Students Physical Self-Concept and Physical Fitness"” }\end{array}$ \\
\hline 14 & $\begin{array}{l}\text { Presentasi rencana Proposal Tesis yang didukung oleh } \\
\text { artikel sesuai focus kajian penelitian }\end{array}$ \\
\hline 15 & $\begin{array}{l}\text { Presentasi rencana Proposal Tesis yang didukung oleh } \\
\text { artikel sesuai focus kajian penelitian }\end{array}$ \\
\hline 16 & Pengumpulan Proposal Tesis \\
\hline
\end{tabular}

\section{2) Lesson plan of inductive method}

TABLE II. LESSON PLAN OF INDUCTIVE METHOD

\begin{tabular}{|c|l|}
\hline Meeting & \multicolumn{1}{|c|}{ Materials } \\
\hline 1 & $\begin{array}{l}\text { Pengenalan Materi Isu Pedagogi dalam Olahraga selama } \\
\text { satu semester (setiap mahasiswa mencari satu artikel } \\
\text { sesuai Fashion masing-masing }\end{array}$ \\
\hline 2 & Bedah artikel untuk mencari masalah penelitian \\
\hline 3 & Bedah artikel untuk mencari masalah penelitian \\
\hline 4 & Bedah artikel untuk mencari masalah penelitian \\
\hline 5 & Bedah artikel untuk mencari Hipotesis \\
\hline 6 & Bedah artikel untuk mencari Hipotesis \\
\hline 7 & Bedah artikel untuk mencari methodology penelitian \\
\hline 8 & UJIAN TENGAH SEMESTER \\
\hline 9 & Bedah artikel untuk mencari methodology penelitian \\
\hline 10 & Bedah artikel untuk mencari methodology penelitian \\
\hline 11 & Bedah artikel untuk mencari methodology penelitian \\
\hline 12 & $\begin{array}{l}\text { Bedah artikel untuk mencari penolakan/penerimaan } \\
\text { hipotesis dan diskusi temuan }\end{array}$ \\
\hline 13 & $\begin{array}{l}\text { Bedah artikel untuk mencari penolakan/penerimaan } \\
\text { hipotesis dan diskusi temuan }\end{array}$ \\
\hline 14 & $\begin{array}{l}\text { Presentasi rencana Proposal Tesis yang didukung oleh } \\
\text { artikel sesuai focus kajian penelitian }\end{array}$ \\
\hline 15 & $\begin{array}{l}\text { Presentasi rencana Proposal Tesis yang didukung oleh } \\
\text { artikel sesuai focus kajian penelitian }\end{array}$ \\
\hline 16 & \begin{tabular}{l} 
Pengumpulan Proposal Tesis \\
\hline
\end{tabular} \\
\hline
\end{tabular}

\section{RESULTS AND DISCUSSION}

The research process has finished the treatment, in midSeptember the posttest was completed for the two sample groups. The data that has been obtained by the researcher is posttest data and data analysis with Independent t-test.

\section{A. Data Posttest}

TABLE III. DATA POSTTEST

\begin{tabular}{|c|c|c|}
\hline \multirow{2}{*}{ Grade } & Deductive & Inductive \\
\cline { 2 - 3 } & Total & Total \\
\hline A & 17 & 21 \\
\hline A- & 13 & 13 \\
\hline B+ & 12 & 10 \\
\hline B & 8 & 7 \\
\hline
\end{tabular}

B. Independent Samples Test Data Analysis

TABLE IV. GROUP STATISTICS

\begin{tabular}{|c|l|c|c|c|}
\hline \multirow{3}{*}{ Result } & Group & N & Mean & Std. Deviation \\
\cline { 2 - 5 } & Inductive & 51 & 3.4961 & .28491 \\
\cline { 2 - 5 } & Deductive & 51 & 3.3863 & .56823 \\
\hline
\end{tabular}

TABLE V. INDEPENDENT SAMPLE TEST

\begin{tabular}{|c|c|c|c|}
\hline $\mathbf{T}$ & df & Sig. (2-tailed) & Mean Difference \\
\hline 1.234 & 100 & .220 & .10980 \\
\hline
\end{tabular}

\section{Hypothesis}

Ho: There is no difference in learning outcomes between groups of inductive and deductive approaches

Ha: There are differences in learning outcomes between groups of inductive and deductive approaches

Decision criteria

If the value of $\mathrm{p}$ (Sig.) $>0.05$ then Ho is accepted

If the value of $\mathrm{p}$ (Sig.) $<0.05$ then Ho is rejected

The value of $\mathrm{t}$-cal is 1.234 with $\mathrm{p} 0.220>0.05$, so Ho is accepted. This means that there are no differences in learning outcomes between groups of inductive and deductive approaches.

Pragmatic field study Takimoto, proves that inductive is very effective, especially when combined with problemsolving methods [14]. Meanwhile, other language research Seliger finds that deductive methods are more effective than inductive methods [15]. The context of this study is in teaching English to foreign speakers. However, this fact is contrary to the results of the study Haight et al., in Grammar teaching that inductive instructional methods are more effective when compared to Grammar teaching using deductive methods [16]. Meanwhile, in the field of nursing, deductive content analysis is used more than the inductive approach [17].

\section{CONCLUSION}

From the results of research on the application of deductive methods and inductive methods in the success of writing a thesis proposal for students of the School of Postgraduate Studies, Universitas Pendidikan Indonesia, there was no significant difference. This means that there is no significantly 
different between both group related to produce the thesis proposal. The next study is suggested to see the application of deductive methods and inductive methods based on gender.

\section{ACKNOWLEDGMENT}

Fitri, Suherman, and Budiana thanks to Allah who help the researchers. All of them also thanks to family, relatives, for supporting to finish the paper. Especially to Rasi Yugafiati for her proof reading. Hope God bleesses us.

\section{REFERENCES}

[1] J.E. Rink, "Investigating the Assumptions of Pedagogy," Journal of Teaching in Physical Education, vol. 20, pp. 112-128, 2001.

[2] C.A. Escot, "The Contribution of Two Research Programs on Teaching Content: "Pedagogical Content Knowledge" and "Didactics of Physical Education"," Journal of Teaching in Physical Education, vol. 20, pp. 78101, 2000.

[3] K.F. Hyde, "Recognising deductive processes in qualitative research," Qualitative market research: An international journal, vol. 3, no. 2, pp. 82-90, 2000.

[4] R.M. DeKeyser, "Learning Second Language Grammar Rules," Stud Second Lang Acquis, vol. 17, no. 03, pp. 379, 2008.

[5] P. Robinson, "Learning Simple and Complex Second Language Rules Under Implicit," Stud Second Lang Acquis, vol. 18, no. 1, pp. 27-67, 1996.

[6] M.F. Rizzuto, "Experimental comparison of inductive and deductive methods of teaching concepts of language structure," The Journal of Educational Research, vol. 63, no. 6, pp. 269-273, 1970.
[7] X. Qi and C. Lai, "The effects of deductive instruction and inductive instruction on learners' development of pragmatic competence in the teaching of Chinese as a second language," System, vol. 70, no. 2, pp. 26-37,2017.

[8] J.N. Perry, R.H. Smith, I.P. Woiwod, D.R. Morse, Chaos in real data: the analysis of non-linear dynamics from short ecological time series (Vol. 27). Springer Science \& Business Media, 2012.

[9] H.F. Marei, J. Donkers, M.M. Al-Eraky and J.J. van Merrienboer, "The effectiveness of sequencing virtual patients with lectures in a deductive or inductive learning approach," Medical teacher, vol. 39, no. 12, pp. 1268-1274, 2017

[10] A.M. Lahti, "The inductive-deductive method and the physical science laboratory," The Journal of Experimental Education, vol. 24, no. 3, pp. 149-163, 1956.

[11] G.W. Lott, "The effect of inquiry teaching and advance organizers upon student outcomes in science education," J Res Sci Teach, vol. 20, no. 5, pp. 437-51, 1983 .

[12] R. Ellis, "Researching the Effects of Form-Focussed Instruction on L2 Acquisition," AILA Rev., vol. 19, no. 1, pp. 18-41, 2007.

[13] R. Erlam, "The Effects of Deductive and Inductive Instruction on the Acquisition of Direct Object Pronouns in French as a Second Language,” Mod Lang J., vol. 87, no. 2, pp. 242-60, 2004.

[14] M. Takimoto, "The effects of deductive and inductive instruction on the development of language learners' pragmatic competence," The Modern Language Journal, vol. 92, no. 3, pp. 369-3861, 2008.

[15] H.W. Seliger, "Inductive method and deductive method in language teaching: A re-examination," IRAL-International Review of Applied Linguistics in Language Teaching, vol. 13, no. 1-4, pp. 1-18, 1975.

[16] C.E. Haight, C. Herron and S.P. Cole, "The Effects of Deductive and Guided Inductive Instructional Approaches on the Learning of Grammar in the Elementary Foreign Language College Classroom," Foreign Language Annals, vol. 40, no. 2, pp. 288-310, 2007.

[17] S. Elo and H. Kyngäs, "The qualitative content analysis process," Journal of Advanced Nursing, vol. 62, no. 1, pp. 107-115, 2008. 